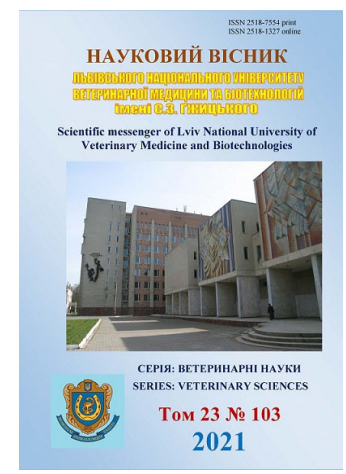

\author{
Науковий вісник Дьвівського національного університету \\ ветеринарної медицини та біотехнологій імені С.3. Гжицького. \\ Серія: Ветеринарні науки \\ Scientific Messenger of Lviv National University \\ of Veterinary Medicine and Biotechnologies. \\ Series: Veterinary sciences
}

UDC 619:616.9:616-036.4:639.3

\title{
Epizootic situation with infectious and invasive diseases in fishery of LLC "Nikolaev RMS"
}

\author{
V. V. Senechyn, R. S. Oseredchuk, E. O. Yakimova \\ Stepan Gzhytskyi National University of Veterinary Medicine and Biotechnologies Lviv, Lviv, Ukraine
}

Article info

Received 05.08.2021

Received in revised form 06.09.2021

Accepted 07.09.2021

Stepan Gzhytskyi National University of Veterinary Medicine and Biotechnologies Lviv, Pekarska Str., 50, Lviv, 79010, Ukraine. Tel.: +38-097-315-21-35 E-mail: senechin@ukr.net
Senechyn, V. V., Oseredchuk, R. S., \& Yakimova, E. O. (2021). Epizootic situation with infectious and invasive diseases in fishery of LLC "Nikolaev RMS". Scientific Messenger of Lviv National University of Veterinary Medicine and Biotechnologies. Series: Veterinary sciences, 23(103), 152-156. doi: $10.32718 /$ nvlvet 10321

Most fish farms in their economic activities for the reproduction and cultivation of fish rely on the use of a set of intensification measures, but, despite them, the spread of infectious and invasive diseases and the deterioration of the epizootic condition does not stop. Fish farms are most exposed to pathogenic effects, as they specialize in raising young fish, which is more susceptible to this type of disease. During the growing season, we conducted hydrobiological and hydrochemical studies, analyzed the epizootic state of the farm, and identified the intensity of the spread of invasive fish diseases in summer and autumn. Because invasive diseases complicate the process of reproduction and rearing of fish, which primarily leads to refusal of food, reducing the intensity of its growth, the death of a large number of aquatic organisms, which causes significant economic losses in the production process. The main purpose of the work was: identifying pathogens of infectious and parasitic diseases to identify them; establishing the intensity of infection; selection of methods of fish treatment and disease prevention in the carp farm of Mykolayivska RMS LLC and Babin-Ryba fish farm. Studies have shown that a significant proportion of fish was affected by pathogens of the class Sestoidea (cestodes): Khawia sinensis (caviosis), Caryophyllosis (karyophilosis) in all age groups, Dyplostomums pathaceum (diplostomosis), Trichodina domerguei forma acdose and three others. (ligulosis), Lernaeosis (Lerniosis), Bothriocephalus acheloignati (botryocephalus). To control the incidence of fish used cestozol, which contains $70 \%$ niclosamide and $30 \%$ levamisole, which helped to overcome the source of infection and curb the incidence. To prevent the occurrence of such phenomena in the future economy, it is recommended to strictly follow the veterinary and sanitary rules and regulations provided by the technological processes of reproduction and cultivation of fish.

Key words: fish, pathogen, cestodes, invasive diseases, hydrobiological and hydrochemical studies, intensification measures.

\section{Епізоотична ситуація 3 інфекційними та інвазійними хворобами у рибному господарстві ТзОВ "Миколаївська РМС"}

\author{
В. В. Сенечин, Р. С. Осередчук, С. О. Якімова
}

Львівський національний університет ветеринарної медицини та біотехнологій імені С. 3. Гжиџького, м. Львів, Україна

Більшість рибних підприємств у своїи господарській діяльності з відтворення та вирощування риби опирається на використанні комплексу інтенсифікаційних заходів, але, незважаючи на них, поширення інфекційних та інвазійних хвороб і погіриення епізоотичного стану не припиняється. Найбільшому патогенному впливу піддаються господарства-риборозплідники, адже вони спеціалізуються на вирощуванні молоді риби, яка є більш сприйнятливою до такого роду захворювань. Впродовж вегетаційного періоду нами були проведені гідробіологічні та гідрохімічні дослідження, проаналізовано епізоотичний стан господарства та виявлення інтенсивності поширення інвазійних захворювань риб у літній та осінній періоди. Оскільки інвазійні хвороби ускладню- 
ють процес відтворення і вирощування риби, щзо насамперед призводить до: відмови від корму, зниження інтенсивності ї̈ росту, загибелі великої кількості гідробіонтів, щчо спричиняє значні економічні збитки у процесі виробництва. Основною метою роботи було: при виявленні збудників інфекиійних та паразитарних захворювань проведення їхньої ідентифікації; встановлення інтенсивності зараження; підбір методів лікування риби та профілактики захворюваності у короповому господарстві ТзОВ “Миколаївська РМС” та рибній дільниці “Бабин-Риба”. Під час досліджень встановлено, шчо значна частина риби була уражена збудниками з класу Cestoidea (иестоди): Khawia sinensis (кавіоз), Caryophyllosis (каріофільоз) у всіх вікових груп, Dyplostomuтs pathaceum (диплостомоз), Trichodina domerguei forma acuta (триходиніоз) а інші Ligulidoses (лігульоз), Lегnаеоsis (лерніоз), Bотhriocephalus acheloignati (ботріочефальоз). Для боротьби із захворюваністю риб використовували цестозол, який містить 70 \% ніклозаміду $і$ 30 \% левамізолу, щчо дозволило побороти вогнище зараження і приборкати захворюваність. Для запобігання виникненню таких явищ в майбутньому господарству рекомендовано чітко дотримуватись ветеринарно-санітарних правил та норм, передбачених технологічними прочесами з відтворення та вирощування риби.

Ключові слова: риба, збудник, цестоди, інвазійні захворювання, гідробіологічні та гідрохімічні дослідження, інтенсифікаційні заходи.

\section{Ветуп}

Для нормального функціонування організму людини необхідно споживати рибу та рибну продукцію, оскільки вони є джерелом надходження білків, необхідних макро- і мікроелементів (Фтор, Цинк, Купрум, Йод) та вітамінів групи В, A, D, які необхідні людям для нормального проходження фізіологічних процесів. Забезпечення населення рибною продукцією є можливим за стабільного функціонування аквакультури, за рахунок якої можна відтворювати популяцію риб у природних водоймах та вирощувати продукцію у штучних (Hrytsyniak \& Hurbyk, 2017; Rudenko et al., 2019; Vodianitskyi et al., 2020; Prychepa et al., 2021; Hrynevych et al., 2021).

Зазвичай при розвитку рибного господарства великого збитку завдають хвороби риб, які спричинені неналежними умовами середовища або коли збудником є найпростіші, гельмінти та ракоподібні. Основними чинниками, які спричиняють виникнення хвороб риб та їх загибель $\epsilon$ недостатній нагляд при перевезенні риби, порушення карантинних заходів, низька якість кормів, погіршення умов вирощування та антропогенне забруднення водойм. Найпоширенішими хворобами, які трапляються в Україні у природних водоймах, є хілоденельоз, триходиноз, іхтіофтіріоз, гіродактильоз, аргульоз, лернеоз, кавіоз, ботріоцефальоз (Horsberg, 2012; Loboiko et al., 2016).

У ставових рибних господарствах трапляються хвороби, викликані як ендопаразитами, так і ектопаразитами. Значну небезпеку для риб становлять ендопаразити, які паразитують у риб, вони дуже патогенні, викликають масові захворювання i загибель, найчастіше молоді. Серед захворювань цьоголіток коропа чільне місце займають хвороби, викликані представниками класу Cestoidea. В організмі риб паразити спричинюють механічний і токсичний вплив, який характеризується ушкодженням слизової оболонки кишок, порушенням травлення та обміну речовин (Fedorovych et al., 2019).

Варто зазначити, що велика чисельність інвазії спричиняє масову смертність риби.

Не менш небезпечними $є$ і ектопаразити, які уражають зовнішні покриви, зябра, особливо це спостерігається після зимівлі риб при щільній посадці у однорічок. Представники роду Lernea спричиняють ураження шкіри, на місці проникнення розвивається запалення. Також паразит виділяє токсини, які призводять до збільшення фагоцитуючих елементів крові (Loboiko \& Danko, 2015).
Виникнення епізоотій спричиняє виснаження риби після зимівлі та невідповідні умови гідрологічного i гідрохімічного режиму, недотримання ветеринарносанітарних норм. $Є$ дані, що хворіє лише молодь, а паразитоносіями $є$ старші вікові групи, але у більшості випадків при високій інвазії гинуть і риби старшого віку.

Мета $і$ завдання дослідження: провести епізоотичне дослідження молоді коропа рибного господарства “Миколаївська РМС” та рибдільниці “Бабин-Риба", визначити поширення епізоотії, ідентифікувати збудника та застосувати оптимальний комплекс лікувально-профілактичних заходів задля ліквідації захворюваності та запобігання їх виникненню.

\section{Матеріал і методи досліджень}

Дослідження проводились у вегетаційний період 2021 року в умовах рибного господарства "Миколаївська РМС" та рибдільниці “Бабин-Риба". Відомості про особливості технології вирощування, щільність зариблення, паразитологічну ситуацію отримували зі звітності рибних господарств та за результатами власних досліджень.

Об'єктами дослідів слугували різні вікові групи коропа (Cyprinus Carpio L.) i товстолоба (Hypophthalmichthys molitrix Val.).

Іхтіопаразитологічний аналіз проводили за методом неповного паразитологічного розтину за I. Є. Биховською-Павловською (Byhovskaja-Pavlovskaja, 1985). Видову належність паразитів визначали за "Определителем паразитов пресноводных рыб фауны СССР" (Bauer, 1987). Для підрахунку виявленого збудника застосовували показники: екстенсивність та інтенсивність інвазії. Екстенсивність інвазії (ЕІ) встановлювали за формулою:

$$
E I=x \div y \times 100,
$$

де, $\quad x$ - кількість риб, у яких виявили паразитів, екз.; $y$ - загальна кількість досліджуваних риб, екз.

Інтенсивність інвазії (II) визначали шляхом підрахунку кількості паразитів на тілі та зябрах досліджуваних риб.

Перед початком дослідження та впродовж вегетаційного періоду досліджували гідрохімічні та гідробіологічні показники. Проби води ставів для аналізу відбирали і опрацьовували за стандартними методиками (Alekin et al., 1973; SOU 05.01.-37-385:2006). 


\section{Результати та їх обговорення}

Гідрохімічні показники. Для вирощування риби вагоме значення має джерело водопостачання та якість води, але не менш важливим фактором для рибного господарства $\epsilon$ застосування комплексу інтенсифікаційних заходів (Senechyn \& Yakimova, 2021).

Погіршення якості води значно впливає на фізіо- логічний стан риби та харчову якість її м’яса. Основні показники гідрохімічного стану води, що визначались, наведені у таблиці 1.

Аналізуючи гідрохімічні показники, можна стверджувати, що вода у ставах відповідає всім вимогам, що, на нашу думку, зумовлено проведенням комплексних інтенсифікаційних заходів.

\section{Таблиця 1}

Гідрохімічні показники якості води у вегетаційний період

\begin{tabular}{|c|c|c|c|}
\hline Показники & $\begin{array}{l}\text { ГДК ОСТ } \\
15.372-87 \\
\end{array}$ & Липень & Вересень \\
\hline Температура, ${ }^{\circ} \mathrm{C}$ & - & 25 & 18 \\
\hline $\mathrm{pH}$ & $6,5-8,5$ & 7,1 & 5,4 \\
\hline $\mathrm{O}_{2}$, мл/л & $6,5-8,5$ & 3,1 & 5,8 \\
\hline Вільний аміак $\mathrm{NH}_{3}$ & до 2,0 & 1,3 & 0,6 \\
\hline $\mathrm{NO}_{3}$, мг $\mathrm{N} / л$ & до 2,0 & 1,5 & 0,8 \\
\hline $\mathrm{PO}_{4}, \mathrm{мг} \mathrm{P/л}$ & до 0,5 & 0,07 & 0,15 \\
\hline Окислюваність перманганатна, мг О/л & до 20 & 15,6 & 22,3 \\
\hline $\mathrm{Fe}$ заг., мг Fe/л & до 1,0 & 0,03 & 0,02 \\
\hline $\mathrm{Mg}$, мг Mg/л & до 30 & 11,2 & 7,8 \\
\hline Загальна твердість, мг-екв/л & $2-6$ & 5,0 & 3,7 \\
\hline Ступінь мінералізації, мг/л & $300-1000$ & 400 & 345,2 \\
\hline
\end{tabular}

Кисневий режим: влітку характеризується низькими показниками вмісту розчиненого у воді кисню (3,1-3,6 мг/л) та значним його збільшенням у вересні (5,8-6 мг/л).

Активна реакція середовища. Вміст амонійного азоту, нітритів, нітратів, Фосфору та Заліза перебуває в межах норми і не перевищує величини гранично допустимих концентрацій.

Природна кормова база представлена в достатній кількості. Під час досліджень було виявлено гіллястовусих ракоподібних, їх кількість становила 50,0 \%, коловертки склали 36,9 \% від усіх видів. Частка веслоногих ракоподібних не перевищувала 13,1 \%. Основними методами стимулювання та підтримання розвитку природної кормової бази $є$ удобрення ставів (мінеральні, органічні добрива - зазвичай використовують гній) та введення високопродуктивних форм безхребетних. У результаті удобрення в ставах інтенсивно розвиваються бактерії та планктонні водорості, які є їжею зоопланктону та зообентосу.

Показники по чисельності та біомасі зообентосу наведені у таблиці 2.

Таблиця 2

Чисельність (N, тис. екз.г/M $\left.\mathrm{M}^{3}\right)$ і біомаса $\left(\mathrm{B}, \Gamma / \mathrm{M}^{3}\right)$ зоопланктону

\begin{tabular}{llll}
\hline \multicolumn{1}{c}{ Місяць } & \multicolumn{1}{c}{$\begin{array}{c}\text { Rotifera } \\
\text { (коловертки) }\end{array}$} & $\begin{array}{c}\text { Cladocera } \\
\text { (гіллястовусі рачки) }\end{array}$ & $\begin{array}{c}\text { Copepoda } \\
\text { (веслоногі рачки) }\end{array}$ \\
\hline \multirow{2}{*}{ Червень } & $\mathrm{N}=0,55$ & $\mathrm{~N}=66,9125$ & $\mathrm{~N}=59,485$ \\
& $\mathrm{~B}=0,013$ & $\mathrm{~B}=5,632$ & $\mathrm{~B}=2,183$ \\
\hline \multirow{2}{*}{ Липень } & $\mathrm{N}=5,530$ & $\mathrm{~N}=50,566$ & $\mathrm{~N}=74,126$ \\
& $\mathrm{~B}=0,008$ & $\mathrm{~B}=2,671$ & $\mathrm{~B}=1,638$ \\
\hline \multirow{2}{*}{ Серпень } & $\mathrm{N}=39,141$ & $\mathrm{~N}=124,832$ & $\mathrm{~N}=271,285$ \\
& $\mathrm{~B}=0,090$ & $\mathrm{~B}=12,436$ & $\mathrm{~B}=3,420$ \\
\hline
\end{tabular}

Проведені епізоотологічні та паразитологічні дослідження в рибних дослідних господарствах вказують на спалахи захворюваності риб, ураження ії̈ ендопаразитами і частково ектопаразитами. Під час роботи було обстежено 1325 екземплярів риби. Паразитологічному розтину було піддано 500 екземплярів мальків та цьогорічок 3 вирощувальних ставів рибного господарства "Миколаївська РМС" та рибдільниці “Бабин-Риба".

Дослідженнями мальків та цьоголіток коропа i товстолоба в "Миколаївська РМС" у період вегетації виявлено паразитів: інфузорії -Trichodina domerguei forma acuta (триходиніоз), цестоди - Khawia sinensis (кавіоз), Caryophyllaeus brachicolis (каріофільоз), Bothriocephalus acheloignati (ботріоцефальоз); сисуни - Dyplostomum spathaceum (диплостомоз). Значна частина риби (35-40\%) уражена ракоподібними Lernaea cyprinacea (лернеоз).

Після зариблення у червні молодь коропа була інвазована трьома видами паразитів: Trichodina domerguei forma acuta (екстенсивність інвазії - 6,0$20,0 \%$ за інтенсивності 0,02-0,03); Dactylogyrus vastator (екстенсивність інвазії $30 \%$ за середньої інтенсивності 8,2).

У липні в мальків коропа у дослідному ставовому господарстві вперше за останні роки було виявлено 
Caryophyllaeus brachicolis (екстенсивність інвазії $60 \%$ за середньої інтенсивності 6,0-20,1 залежно від середньої маси); Trichodina domerguri forma acuta (екстенсивність інвазії $9 \%$ за середньої інтенсивності 0,02).

Одним 3 найпоширеніших плоских гельмінтів $\epsilon$ Khawia sinensis та Caryophyllaeus fimbriceps. Зараження риби відбувається при поїданні нею трубочника (олігохети), який є проміжним господарем. Спалахи даної епізоотій виникають при недотриманні ветеринарно-санітарних норм. Найсприятливішим середовищем для даного збудника $є$ водойми із мулистим дном де олігохети швидко розвиваються, і кавіоз та каріофільоз можуть протікати у формі епізоотичних спалахів. У трубочника впродовж 2-3 місяців формуються інвазовані личинки - процеркоїди. У кишках риб гельмінти ростуть і через $1,5-2,5$ місяця досягають статевозрілої стадії. За останні роки епізоотія сягає $3 \%$.

Зараженість коропа Dyplostomum spathaceum в ставах становила $18 \%$ за середньої інтенсивності 1,4; Khawia sinensis (екстенсивність інвазії $40 \%$ за середньої інтенсивності 0,06); Dactylogyrus vastator (екстенсивність інвазії $25 \%$ за середньої інтенсивності 8,6). Паразитологічний стан наведено в таблиці 3.

Таблиця 3

Паразитологічний стан “Миколаївська РМС” та рибдільниці “Бабин-Риба”

\begin{tabular}{|c|c|c|c|c|}
\hline \multirow{2}{*}{ Збудник } & \multicolumn{2}{|c|}{ “Миколаївська РМС” } & \multicolumn{2}{|c|}{ “Бабин-Риба” } \\
\hline & Екстенсивність інвазії, \% & Інтенсивність інвазії & Екстенсивність інвазії, \% & Інтенсивність інвазії \\
\hline & & Червень & & \\
\hline Триходиніоз & $6,0-20$ & $0,02-0,03$ & & \\
\hline Дактилогіроз & 30 & $\begin{array}{c}8,2 \\
\text { Липень }\end{array}$ & 30 & 8,2 \\
\hline Каріфільоз & 60 & $6,0-21,0$ & 55 & $6,0-20,0$ \\
\hline Триходиніоз & 9 & 0,02 & & \\
\hline Диплостомоз & 18 & 1,4 & 18 & 1,4 \\
\hline Кавіоз & 40 & 0,06 & & \\
\hline Лерніоз & 60 & $\begin{array}{c}5-10 \\
\text { Серпень }\end{array}$ & 60 & $5-10$ \\
\hline Ботріоцефальоз & 5,6 & 0,9 & & \\
\hline Лерніоз (короп) & 65 & $8-14$ & 65 & $8-14$ \\
\hline Лерніоз (товстолоб) & 74 & $6-9$ & & \\
\hline
\end{tabular}

В серпні у вирощувальних ставах рибдільниці вперше за останні 5 років виявили Bothriocephalus acheloignati (екстенсивність інвазії 5,6 \% за середньої інтенсивності 0,9). У двох дослідницьких ставах рибдільниці “Бабин-Риба" зафіксовано Caryophyllaeus brachicolis (екстенсивність інвазії $60 \%$ за середньої інтенсивності 6,0-21,0 екземплярів); Lernaea cyprinacea (екстенсивність інвазії 65 \% при середній інтенсивності 8,14 у молоді коропа).

У ставах екстенсивність зараження коропа Lernaea cyprinacea становила 59-62 \% за середньої інтенсивності 8-14 штук на рибу. Зараження лерніями товстолоба становила 74 \% за середньої інтенсивності 6-9 паразитів на рибу.

Під час клінічного огляду було виявлено рибу зі значною кількістю збудника на тілі, яка відмовлялася від корму. Під час огляду риб на поверхні тіла виявили пошкодження шкіри та поверхневих шарів м'язової тканини. У місцях паразитування лерній утворювались локальні ущільнення червоного кольору, які в окремих випадках перетворювались у виразки. Всередині виразки було виявлено рачка Lernaea. Краї виразки були червоного кольору, у деяких особин - сіруватого. Запальний процес поширювався на поверхневі шари і в глибину м'язової тканини. Також паразит виділив токсини, які призвели до збільшення фагоцитуючих елементів крові.

За останні роки господарству значної шкоди завдавали крустацеози - лернеоз (Lernea cyprinacea). Причиною спалаху хвороби є порушення санітарно- рибоводних правил та неправильне утримання риби. У результаті - риба втрачає товарний вигляд через виразки на тілі.

Для боротьби 3 каріофільозом і кавіозом в експерементальні стави вносили корм разом 3 лікарським препаратом. Основним препаратом слугував цестозол, який на 70 \% складається з ніклозаміду і 30 \% - 3 левамізолу.

Для проведення дегельмінтизації необхідно приготувати лікувально-кормову суміш (ЛКС): 1 кг препарату ретельно перемішували з 99 кг корму. Лікувальна (добова) доза ЛКС для кожної водойми становить 1,5 \% від розрахункової маси риби. Дозу ділили на 56 рівних порцій, які вносили з інтервалом 1-2 години в певні місця годування протягом доби. Паразитологічний огляд риби після застосування ЛКС показав значне зменшення інтенсивності інвазії.

За результатами проведених досліджень можна констатувати, що молодь коропа заразилась внаслідок недотриманням санітарних правил в господарствах, це спричинило значну загибель риби і затрати на іiі лікування, погіршило економічне становище рибного господарства "Миколаївська РМС" та рибдільниці “Бабин-Риба".

\section{Висновки}

У водоймах дослідних господарств Львівської області спостерігаються вогнища інвазійних хвороб риб. До найпоширеніших гельмінтозів належать кавіоз i 
каріофільоз, які трапляються в коропових риб по всій території регіону. Особливо небезпечними для коропових риб є крустацеози - лернеоз. Як показали результати досліджень, у боротьбі 3 даними видами захворювань використовувалися препарати сильної дії, для того щоб уникнути масової загибелі риб.

Перспективи подальших досліджень. Дослідження будуть спрямовані на більш поглиблене вивчення особливостей біології збудників у рибних господарствах досліджуваного регіону. Триватиме пошук оптимальних методів профілактики з метою запобігання виникненню захворюваності риб. Доцільне удосконалення методів лікування цих захворювань задля уникнення загибелі риб, що призводить до значних економічних втрат.

\section{Відомості про конфлікт інтересів}

Автори стверджують про відсутність конфлікту інтересів.

\section{References}

Alekin, O. A., Semenov, A. F., \& Skopincev, V. A. (1973). Rukovodstvo po himicheskomu analizu vod sushi. Leningrad: Gidrometeoizdat (in Russian).

Bauer, O. N. (1987). Opredelitel' parazitov presnovodnyh ryb fauny SSSR: v 3 t. Lenigrad: Nauka. T. 3: Paraziticheskie mnogokletochnye (in Russian).

Byhovskaja-Pavlovskaja, E. I. (1985). Parazity ryb. Rukovodstvo po izucheniju. Leningrad: Nauka (in Russian).

Fedorovych, O., Gutyj, B., Fedorovych, V., \& Chornyi, I. (2019). Epizootic situation on fish invasion diseases in the waters of Ukraine. Scientific Messenger of LNU of Veterinary Medicine and Biotechnologies. Series: Veterinary Sciences, 21(96), 95-100. doi: $10.32718 /$ nvlvet9617.

Horsberg, T. E. (2012). Avermectin use in aquaculture. Curr. Pharm. Biotechnol., 13(6), 1095-1102. doi: $10.2174 / 138920112800399158$.

Hrynevych, N., Prychepa, M., Kovalenko, Yu., Vodianitskyi, O., Svitelskyi, M., Fotin, O., Zahorui, L., Zharchynska, V., Gutyj, B., Kulish, S., Honcharenko, V., Velesyk, T., Sachuk, R., Stravsky, Ya., Boltyk, N. (2021). The role of macrophytes in waterfowl reproduction. Ukrainian Journal of Ecology, 11(2), 320-326. doi: 10.15421/2021_117.

Hrytsyniak, I. I., \& Hurbyk, V. V. (2017). Otsinka tovarnykh kondytsii riznovykovykh hrup halytskoho koropa. Naukovyi visnyk LNUVMBT imeni S. Z.
Gzhytskoho, 19(74), 29-32. doi: 10.15421/nvlvet7407 (in Ukrainian).

Loboiko, Yu. V., \& Danko, M. M. (2015). Terapevtychna ta ekonomichna efektyvnist zastosuvannia brovermektyn-hranuliatu za ektoparazytoziv koropa. Naukovyi visnyk Lvivskoho natsionalnoho universytetu veterynarnoi medytsyny ta biotekhnolohii imeni S. Z. Gzhytskoho, 17(2(62), 124-130 (in Ukrainian).

Loboiko, Yu. V., Stybel, V. V., \& Danko, M. M. (2016). Terapevtychna efektyvnist protyparazytarnykh preparativ $\mathrm{z}$ hrupy makrotsyklichnykh laktoniv ta imunomoduliatora za lerneozu koropa. Biolohiia tvaryn, 18(1), 87-92. doi: 10.15407/animbiol18.01.087 (in Ukrainian).

Prychepa, M., Hrynevych, N., Martseniuk, V., Potrokhov, O., Vodianitskyi, O., Khomiak, O., Rud, O., Kytsokon, L., Sliusarenko, A., Dunaievska, O., Gutyj, B., Pukalo, P., Honcharenko, V., Yevtukh, L., Bozhyk, L., Prus, V., Makhorin, H. (2021). Rudd (Scardinius Erythrophthalmus 1., 1758) as a bioindicator of anthropogenic pollution in freshwater bodies. Ukrainian Journal of Ecology, 11 (2), 253260. doi: 10.15421/2021_108.

Rudenko, O. P., Paranjak, R. P., Kovalchuk, N. A., Kit, L. P., Hradovych, N. I., Gutyj, B. V., Kalyn, B. M., Sukhorska, O. P., Butsiak, A. A., Kropyvka, S. I., Petruniv, V. V., \& Kovalska, L.M. (2019). Influence of seasonal factors on carp fish immune reactivity. Ukrainian Journal of Ecology, 2019, 9(3), 168-173. URL: https://www.ujecology.com/abstract/influenceof-seasonal-factors-on-carp-fish-immune-reactivity44508.html.

Senechyn, V., \& Yakimova, E. (2021). Technology of growing young carp in fish farm Ltd "Mykolaivska RMS”. Scientific Messenger of LNU of Veterinary Medicine and Biotechnologies. Series: Agricultural Sciences, 23(94), 56-60. doi: 10.32718/nvlvet-a9411.

SOU 05.01.-37-385:2006 (2006). Voda rybohospodarskykh pidpryiemstv. Zahalni vymohy ta normy. Kyiv: Ministerstvo ahrarnoi polityky Ukrainy (Standart Minahropolityky Ukrainy) (in Ukrainian).

Vodianitskyi, O., Potrokhov, O., Hrynevych, N., Khomiak, O., Khudiyash, Y., Prysiazhniuk, N., Rud, O., Sliusarenko, A., Zagoruy, L., Gutyj, B., Dushka, V., Maxym, V., Dadak, O., Liublin, V. (2020). Effect of reserviour temperature and oxygen conditions on the activity of Na-K pump in embrios and larvae of perch, roach, and ruffe. Ukrainian Journal of Ecology, 10(2), 184-189. doi: 10.15421/2020_83. 